\title{
Reklamların Eskimeyen
}

\section{Yüzü "Muhteșem Annelik" Anneler Günü Reklamları Örneği}

\section{Sevil Bal}

Başkent Üniversitesi

Halkla illişkiler ve Tanıtım Bölümü

\section{Özet}

Feminist eleștirel teori, geçtiğimiz yüzyılda ağırlık kazanan feminist medya çalıșmaları düzleminde, kadınlık durumunun medya kurumu ve medya metinlerindeki temsil konularına yönelik çalıșmalar gerçekleștirmektedir. Kușkusuz bu çalıșmalarda ve söz konusu metinlerde, kadınlık durumunun "annelik" miti ile biçimlendiği toplumsal cinsiyet rolleri ve kalıp yargılarına yönelik vurgular da söz konusudur. Annelik durumunun, gündelik yașamda kanıksanmıș toplumsal cinsiyet pratikleriyle biçimlenmesi, bu pratiklere ilișkin toplumsal kodların sembolik düzlemde yeniden üretimi ve anneliğin bir tüketim metası olarak dolașıma sokulması bağlamında anlam kazanmaktadır. Bu bakımdan, medya kurumu ve metinleri, annelik mitinin üretimi ve yeniden üretimi sürecinde ele alınması gereken temel bir dinamik olarak karșımıza çıkmaktadır. Bu çalıșmada internet reklamlarında annelik mitinin söylemsel olarak nasıl kurulduğunu göstermek amacıyla anneler günü kampanyalarında anneliğin hangi vurgularla temsil edildiği ve toplumsal cinsiyet rollerinin nasıl meșrulaștırılarak yeniden üretildiği ele alınmaktadır.

Anahtar Sözcükler: Toplumsal cinsiyet, annelik, kalıp yargı, söylem, reklam. 


\section{"Magnificent Motherhood" Unaging Face of Advertisements The Sample of Mother's Day Advertisements}

\section{Sevil Bal}

\section{Başkent University Faculty of Communication}

Department of Public Relations and Publicity

\section{Abstract}

Over the past century, feminist media studies have become more important and many studies have been done by the researchers of Feminist Critical Theory about the representation of female status in the media institutions and texts. In some of these studies, gender roles and stereotypes, in which women's status is shaped by "the myth of motherhood", are highlighted. The formation of motherhood by the practices of the gender that is accustomed in everyday life makes sense in the context of reproduction of social codes relating to these practices on the symbolic plane and the introduction into circulation of motherhood as a commodity of consumption. At this point, the media institutions and texts emerge as basic dynamic which needs to be addressed in the process of production and reproduction of motherhood myth. For these reasons, this study discusses how gender roles are reproduced and legitimized, and how the representation of motherhood is emphasized in the Mother's Day campaign ads.

Keywords: Gender, motherhood, stereotypes, discourse, advertisement. 
Toplumsal cinsiyet yazını; ataerkil sistem, kamusal alan/özel alan, eril iktidar gibi günlük yaşam pratiklerini etkileyen konuları kuramsal inşasının merceğine yerleştirerek, cinsiyet temelinde, toplumsal roller ve kalıp yargıların inşa sürecine dair eleştirel analizler geliştirmektedir. 20. yüzyılın son çeyreğinde feminist medya çalışmaları içerisinde ön plana çıkan, medyada kadınlık durumunun temsili üzerine yapılan araştırmalar, günlük yaşam pratiklerinde üzeri örtülü biçimde işleyen yapı, kurum ve süreçleri görünür kılmak noktasında önemlidir. Medyadaki kadın temsili konusunun tanımlandığı üç önemli alan içerisinde "kadınların medya sektöründeki varlığı", "medya ürünlerinin kullanıcıları/ tüketicileri olarak kadınlar" ve "medya metinlerinde temsil edilme biçimleri" bulunmaktadır (Çelenk 2010, s.229). Medya metinlerindeki temsil vurgusu önemlidir. Çünkü, toplumsal cinsiyet pratiklerinin temel dinamikleri, diğer kurumlar gibi, medya kurumu ve bizzat reklam metinlerine yerleştirilerek yeniden inşa edilmektedir. Medyada kadınlar, belirli sosyokültürel kalıplar çerçevesinde ve toplumsal cinsiyet rol ve kalıp yargılarının sinırlılıklarında, baskın bir patriyarkal ideolojik art alanın getirdikleriyle temsil edilmektedir. Söz konusu toplumsal rol ve kalıp yargıların tipik bir örneği, kadınlık durumunun "doğası" ile özdeşleştirilen; fakat eril emeğin yeniden üretimine yönelik bir sorumluluk alanını tanımlayan, ataerkil sistemin üzeri- 
ne giydiği "fedakar bir kılıf" olarak "annelik" olgusudur. Feminist araştırmaların tarihsel arka planına bakıldığında da aynı vurgu ön plana çıkmaktadır. Bu vurgu, kadınlık durumunun yegane var oluş amacının anne olma pratiği üzerine inşa edildiği denetimli bir kuruluşa işaret etmektedir. Dolayısıyla bu bağlamdaki bir farkındalık, eleştirel feminist yaklaşım içerisinde, kadınlık ve annelik durumunu "temsil" ekseninde ele alan öncül ve tarihsel bir takım değerlendirmelerin öne çıkarılmasını gerektirmektedir.

Bu tür öncül çalışmalar kapsamında incelenen reklamlarda; kadınların anne, ev kadını ve eş niteliklerinin bileşiminden oluşturulan bir kategori ile kamusal ve özgür kadın imgeleriyle meydana gelen ikili bir temsilin varlığına dikkat çekilmektedir (Timisi 1997, s.36). Bir diğer ikili temsil kategorisi de, "fettan/ kötü kadın" ile toplumsal cinsiyet rol ve kalıp yargılarına uygun davranan "iyi eş ve anne" olarak kadındır. Bahsedilen bu kadınlık temsillerinin dışındaki kadınlık durumları ise, bizzat bu metinler tarafından marjinalleştirilmekte ve dışarıda bırakılmaktadır (Gencel Bek ve Binark 2000, s.4). Temsil konusunun feminist araştırmalar içerisinde yer bulan bir diğer önemli boyutu, medyada kadınların konu edildiği metinlerin görsel içerikleri ile metinlerinin dili ve söylemsel kuruluşudur (Alankuş 2009, s.107). Çünkü toplumsal cinsiyet kuruluşuna dair gelişen yeniden inşa sürecinde dilin önemi yadsınamayacak niteliktedir. Annelik durumunun söylemsel kuruluşu, reklamlardaki geleneksellik, fedakarlık, titizlik, özveri, ev merkezlilik gibi birtakım kodlar içermekte, tüketime yönelik bir meta ve bir "annelik kurgusu" haline gelmektedir. İronik bir biçimde, annelik miti de kendisini böyle bir tüketim ve yaşam tarzıyla var etmektedir. Feminist bakış, medyanın politik mücadelenin taraflarından biri olduğunu ve onun toplumsal cinsiyet bağlamında oluşturduğu içeriklerin üretimine yönelik sorumlu bir duruşa da sahip olması gerekliliğinin altını çizmektedir (Doğanay ve Kara 2011, s.78). Aksi takdirde bu yeniden üretim sürecinin, eleştirel feminist teorinin dikkat çektiği toplumsal cinsiyet temelindeki yapısal problemleri görünmez kılması kaçınılmazdır. Bu noktadan hareketle, bu çalışma, Türkiye' de son beş yıl içinde farklı sektörlerde faaliyet gösteren firmaların internet sayfalarında yayınlanan anneler günü temalı ilan ve broşürlerden seçilmiş reklam metinlerindeki annelik mitinin işleniş biçimini, oluşturduğu söylemler üzerinden eleştirel feminist teorinin bakış açısıyla değerlendirerek, doğallaştırılmış bir annelik durumunun görünür kılınması amaçlamaktadır. Ayrıca, reklamlardaki annelik kurgusunun hangi toplumsal ve kültürel kodlarla temellendirildiği, böyle bir kurgunun ne tür toplumsal cinsiyet temelli karşıtlıkları beslediğine de bakılacaktır. Bununla birlikte, son olarak, kadınlık durumunun, aile ve annelikle birlikte var 
olabildiği bir belirlenmiş tanımlamalar bütününden sıyrılarak kendine ait bir var olma alanı oluşturma mücadelesinin zamansal mekânsal ve toplumsal karşılıklarına vurgu yapan "Kendine Ait Bir Oda"yı yaratıp yaratamayacağı sorularına yanıt aranmaktadır. Virginia Woolf'un kitabına ismini veren "Kendine Ait Bir Oda" ifadesi; kadınların edebiyat dünyasının eril belirlenimi içerisindeki var olma çabasının ön gereklerini, aile, ebeveyn olma, ev içi emeğin yeniden üretimi sorumluluğu ile ilişkilendirmektedir. Daha yakından bakıldığında, bu ifadenin aslında kadınların birçok farklı alanda var olabilmesinin önündeki temel engelleri de vurguladığı görülmektedir. Çünkü buradaki "oda" metaforu, kadınların aile olma ile belirlenmiş toplumsal cinsiyet rol ve kalıp yargılarından azade "kendileri için, kendilerinin belirlemiş olduğu zaman ve mekanlarda” özerkleşmeye bağlı bir özgürleşme dinamiğine vurgu yapmaktadır (Woolf, 2012).

\section{Cinsiyet ve toplumsal cinsiyet bağlamında kurulan annelik miti ve reklamlardaki temsili}

Reklam metinleri içerisinde yer alan annelik kurgusunun oluşturulma biçimi çok boyutlu bir sürece işaret etmektedir. Söz konusu metinlerdeki annelik miti, ataerkil sistem içerisinde toplumsal yaşamda karşılığı bulunan değerlerle ilişkilendirilerek konumlandırılmakta, aynı zamanda sürekli olarak benzer metaforların kullanımıyla benzer anlamların üretildiği cinsiyetlendirilmiş emek süreçlerini, toplumsal rol ve sorumlulukların doğallaştırılmış ayrıştırıcı niteliğini, kamusal ve özel olarak isimlendirilen alanlardaki ayrımı meşrulaştıran bir anlam bütününü inşa etmektedir. Hem bu çoğul anlamlı kurguyu açıklığa kavuşturmaya çalışmak hem de kuramsal içeriğin ve reklam incelemelerinin daha anlaşılır kılınabilmesi bakımından günlük yaşam içerisinde birbirlerinin yerine kullanılan; fakat tanım ve içerikleri birbirinden farklı olan cinsiyet ve toplumsal cinsiyet kavramlarını ele almak gerekmektedir. Toplumsal cinsiyet yazını, feminist medya çalışmaları ve reklamlardaki annelik temsili açısından bu ikili ayrım önemli bir yer tutmaktadır. "Cinsiyet, kişinin kadın ya da erkek olarak gösterdiği genetik, fizyolojik ve biyolojik özellikleri olarak tanımlanmaktadır" (Vefikuluçay vd. 2007, s.27). Cinsiyet kavramının yeni ve eleştirel bir yeniden ifadesini içeren toplumsal cinsiyet kavramı ise; "kadın ve erkeğin sosyokültürel açıdan tanımlanmasını, toplumların kadın ve erkeği birbirinden ayırt etme biçimini ve onlara verdiği toplumsal rolleri ifade etmektedir" (Bhasin 2003, s.1). Tanımlardan da anlaşılacağı gibi cinsiyet kavramı daha çok biyolojik bir temele dayandırılırken; toplumsal cinsiyet 
kavramında, cinsiyet olgusunun günlük yaşam pratiklerini içeren sosyal ve kültürel nitelikleri ön plana çıkmaktadır.

Cinsiyet ve toplumsal cinsiyet kavramları birbirlerinden farklı anlamlar içerdiği halde; toplumsal cinsiyet rol ve kalıp yargılarının, biyolojik cinsiyet kavramına dayandırılarak meşrulaştırıldığını söylemek mümkündür. Bu meşrulaştırmanın dayanağını da erkek egemen güç ilişkilerini ifade eden ataerkillik kavramı oluşturmaktadır. Ataerkil sistem, bir diğer ifadeyle patriyarka, tarihsel süreç içerisinde öncelikle yönetimi ve tahakkümü altında bulundurduğu "erkek egemen hane" kavrayışına karşılık gelirken, günümüzde daha çok kadınların üzerindeki erkek egemen tahakküm yapısına ve eşitsiz güç ilişkilerine vurgu yapan bir sistemi ifade etmektedir. Ataerkil sistem çevresinde kurulan hiyerarşik yapılanmaya yönelik bir farkındalık günümüzde kadınlar ve erkekler arasındaki ilişkileri anlamak açısından da önemlidir (Bhasin 2003, s.16). Çünkü patriyarkanın, özel ve kamusal olarak tanımlanan alandaki köklü yerleşikliği; bireylerde ve aile, medya, eğitim, ekonomi gibi toplumsal pratikler üzerinde belirleyici önemi bulunan kurumlarda normalize edilmiş bir hiyerarşik rol dağılımı sürecini beraberinde getirmektedir. Bu kurumların içerisinde yer alan medya ve yine bu kapsamda değerlendirilebilecek olan reklam kampanyaları, annelik temsilini adeta görünmez bir kılıf olarak üzerinde giymekte ve bu yolla cinsiyet temelinde oluşturulan bir toplumsal cinsiyet vurgusunun kodlarını yeniden üretmektedir.

Toplumsal cinsiyet rollerinin ataerkil sistem içerisinde güç ilişkilerine dayanan hiyerarşik düzenlenişi, bireylerin cinsiyetleri nedeniyle karşılaştıkları ayrımcı uygulamaları ve temel hizmetlere/kaynaklara ulaşma, toplumsal yaşamda adil temsil edilme ve şiddete maruz kalma bakımından eşitsiz konumlarını tanımlayan toplumsal cinsiyet eşitsizliği kavramına işaret etmektedir (Demirbilek 2007, s.14). Bu eşitsiz ilişkilerin pratikteki karşılıkları ise toplum tarafından tanımlanan ve cinsiyetler temelinde yerine getirilmesi beklenen toplumsal roller (Dökmen 2010, s.16) ve kadınlık ve erkeklik durumuna "uygun görülen" bu nitelik ve davranışların kronikleşmiş durumu olarak tanımlanabilecek kalıp yargılar olarak karşımıza çıkmaktadır. Gerek toplumsal cinsiyet rolleri gerekse kalıp yargılar doğuştan bireye içkin değildir; ancak toplumsallaşma süreciyle cinsiyetlere özgü normal nitelikler olarak gelenekselleştirilmiştir. Bu noktada annelik durumuna da kadının doğurganlık potansiyelinden hareketle merhamet, fedakarlık, güven, sadakat, koruma ve adanmışlık gibi bir dizi toplumsal cinsiyete ilişkin rol ve kalıp yargılar atfedilerek kadının anne olmasının yüceltildiği ve aksinin "sorun" ifade ettiği bir toplumsal çerçeve kazandırılmaktadır. 
Toplumsal cinsiyet rol modelleri ve kalıp yargılarını içeren belki de en tipik durum olan anneliğin inşasının oluşturulması süreci bu nedenle incelenmeye değerdir. Kalıp yargıların tanımında vurgulanan toplumsal rollerin cinsiyetler temelinde kronikleşmesi ve beklentilere dönüşmesi durumunda, kadının evlilik öncesinde toplumsallaşma süreci ile edindiği annelik formasyonuna, evlilik sonrasında baskı mekanizmaları, görevler silsilesi ve yeni rol modeller eklemlenmektedir. Kadın, anne olarak, toplum içindeki hayatını kamusal ve özel alan ikilemi içerisinde devam ettirmektedir. Toplumdaki verili iş bölümünde erkek ve babanın bulunduğu alan ve konumlardan da kendisi için öngörülen özellikler noktasında farklılaşmaktadır.

Çalışma yaşamında da kadınlık ve erkeklik durumlarını ekonomik düzlemde farklılaştıran toplumsal cinsiyet rol ve kalıp yargıları söz konusudur. Bunlardan önemli bir tanesi, erkeği kamusal alanla özdeşleştiren "aile ücreti" (family wage) kavramıdır. Aile içerisinde eş ve çocukların yaşamlarını sürdürmelerini sağlayacak öncül ekonomik kaynağın erkekler tarafından elde edilmesini vurgulayan bu kavram, aile ücretini "yaşama ücreti" olarak tanımlayan Yıldız Ecevit'in ifadesiyle; "Eş ve çocuklarını geçindirip onlara bakabilen çalışkan ve saygıdeğer erkek imgesine duyulan gereğin" (1993, s.21) bir sonucudur. Diğer yandan, erkeklik durumuyla eşleştirilen bu yegane gelir kaynağının yeterliliği ile eş ve çocukların çalışma yaşamına katılma zorunluluklarının ortadan kalkıp kalkmadığına ilişkin birçok tartışma bulunmaktadır. Annelik ile eşleştirilen bir kadınlık durumundan öncelikli beklenti ise, ev içi yeniden üretim olarak tanımlanan ve iktisadi anlamda herhangi bir karşılığı bulunmayan görünmez emek faaliyetleri bütününün sürdürülmesine yöneliktir. Dolayısıyla özel alan olarak tanımlanan bir mekânsal kurgu içerisinde, annelik ve kadınlık rollerinin aynı düzeyde ve yeterlilikle sürdürülmesinin adeta bir zorunluluk olarak öne çıktığı ve bir anne olarak kadının ancak ev sorumluluklarını aksatmayacak şekilde çalışmasının mümkün olabildiği görülmektedir. Çalışma yaşamına kısmen dahil olabilen kadınlar da kendilerine atfedilen ev içi kadınlık ve annelik sorumluluklarını azaltmak bir yana, tüm annelik kodlarına uygun davranışlar sergileme ve aynı zamanda çalışma yaşamında başarılı olmaları şartıyla toplum tarafından başarılı kabul edilerek yüceltilmektedirler. Profesyonel eğitim veya yetkinlik gerektiren yönetsel bir takım görevleri üstlenmede veya terfi konusunda evli ve anne olan kadınlara yönelik cam tavan uygulamalarıyla karşılaşılmaktadır. Bunun d1şında enformel sektördeki kadın istihdamı, düşük ücretli, güvencesiz ve geçici işler, kadınların elde ettikleri gelirin aile gelirine "katkı" olarak ifadelendirilmesi, toplumsal cinsiyet temelli gerçeklikler olarak karşımıza çıkmakta ve 
kadınların çalışma yaşamında var olabilmesinin beraberinde getirdiği annelik durumunu da kapsayan toplumsal kodlara ilişkin problematiği berraklaştırmaktadir.

Reklam metinlerinin doğallaştırılmış kurgusunda da bu ön kabulden sıklıkla faydalanılmaktadır. Söz konusu metinlerde kadınlık durumu, annelik içgüdüsünden kaynaklanmak zorunda olan bir duygusallık ile ön plana çıkarılmakta, annelik genellikle özel alandaki mutlu ve memnun konumuyla işaretlenmektedir. Kamusal alanda nispeten var olabilen bir anne ise ev içi sorumluluklarını öncelikli olarak eşinin ve çocuklarının bakımı ile sınırlı tutmakta, dolayısıyla kamusal alan ve özel alanda kendisinin belirleyemediği koşullarda; fakat kendisinin planlamak zorunda kaldığı bir iş bölümüyle var olabilmektedir. Medya metinlerinde yer alan bir takım kodlarla erkeklik durumu, biyolojik özellikler ve güç merkezli üstünlük gerekçelerine dayandırarak meşrulaştırılmaktadır. Erkeklik, bir yandan, egemenlik, güç, cesaret, mücadeleci karakter gibi özelliklerle tanımlamakta; öte yandan, kamusal alan ve kurumlarda da egemenliğini; aile reisliği, mülkiyet sahipliği, yönetici ve denetleyici olma gibi vasıflarla ilan etmektedir. Bunun karşısında aynı medya metinlerinde, toplum içerisinde düzenleyici ve işlevsel özellikleriyle ön plana çıkarılan kadınlık durumu, annelik, merhamet, özel alan ve fedakârlık gibi toplumsal yaşamda belirli pratiklere karşılık gelen kodlarla özdeşleştirilmekte ve kadının özel alanda görünmeyen, bağımlı ve ataerkil yapı tarafından türetilmiş olumsuz ve ikincil konumu yeniden üretilmektedir. Reklam metinlerinde açık veya örtük bir biçimde yer alan bu tür ifadeler, ataerkil yapı içerisinde adil biçimde bölümlenmemiş toplumsal cinsiyet rolleri ve kalıp yargılarının dilsel ve toplumsal kurgulanış biçimine işaret etmektedir. Söz konusu metinlerin birçoğunda benzer örüntülerle karşılaşılmaktadır. Bu yargılar cinsiyet kavramının bir uzantısı olarak algılanmakta ve toplumsallaşma süreci içerisinde bireylere daha küçük yaşlardan itibaren aktarılarak yeniden üretilmektedir. Toplumsal cinsiyet rol ve kalıp yargılarına aykırı hareket eden bireyler ise yine toplumsal mekanizmalar tarafından formel olmayan bir takım yaptırımlara maruz kalmaktadır.

Dikkatle bakıldığında reklam metinlerinin de bir ürün veya hizmeti tanıtırken, toplumsalda karşılığı bulunan bir takım kod ve sembolleri sorgulamaksızın ve normalleştirerek kullandığı görülmektedir.

Reklam ve reklamcılık, tüketim kültürü ile halk kültürünün karşılıklı etkileşimini yansıtan; pazar ekonomisinin gelişmesi sonucunda, özellikle üretici firmalarla tüketiciler arasında doğan "iletişim boşluğu"nu gideren bir "mesajlar 
bütünü"dür. Reklam ve reklamcılık, bugün yaşamımızı şekillendiren ve yans1tan en önemli kültürel unsurlardan biridir. Öyle ki, reklam ve reklamcılık artık günlük yaşantımızın kaçınılmaz bir parçası haline gelmiştir. Bütün medyatik alanları kapsayan ve hemen hemen hiçbir sınır tanımayan reklamcılık, açıkça özerk bir var oluşu ve muazzam bir etki gücüne sahip geniş bir üst yapıyı oluşturmaktadır (Williamson 2001, s.11).

Feminist çalışmalar dahilinde kadın ve reklam üzerine gerçekleştirilen analizlerde reklamlara ilişkin ve hedef kitleye ulaşabilmeye yönelik iki temel stratejiden bahsedilmektedir.

Reklamlarda bilgileri iletmenin iki yolu, metin ve görsel ögelerdir. Reklamlardaki sözel ve görsel unsurlar okuyucunun duygularını ve inançlarını harekete geçiren göstergelerdir. Bu duygular ve inançlar bir takım kodlara dayanmakta ve çeşitli birleşimlerle metafor, gösterge ve simgeler aracılığıyla işleme girmektedir (Berger 1991, s.125-126).

Dolayısıyla tam da bu noktada, toplumsal cinsiyet pratikleriyle biçimlendirilen bir kadınlık durumunun, fakat bu "kadınlık durumu"nun da ötesinde, yine toplumsal cinsiyetin kuruluşuna temas eden, geleneksel motiflerle donatılmış, titizlik, fedakarlık, özveri ve özel alan aidiyeti gibi çoğaltılabilecek niteliklerle donatılmış "annelik kurgusu" nun reklamlar aracılığıyla tüketime ve yaşam tarzına yönelik bir meta haline geldiği bir sürecin yeniden üretildiğini söylememiz mümkündür.

\section{Yöntem}

Söylem ve söylemin kuruluşuna ilişkin olarak yapılan bir değerlendirme, görsel ve yazı içeren bir metinin fiziksel biçiminin ötesine geçerek, bu metnin görünmezindeki ya da art alanındaki anlamı ve amacı görünür kılmaktadır. "Söylem, belli bir anda bir kurumun programı olarak görülebilir, başka anda sessiz kalan bir pratiği haklı göstermenin, maskelemenin aracı olabilir ya da pratiğe yeni bir rasyonellik alanı açabilir" (Foucault 2005, s.120). Bu noktada annelik kurgusunu ve yeniden üretimini görünmez kılan bir takım dinamiklerin ortaya çıkarılmasında söylem analizi tekniği katkı sağlayacaktır. 1960'larda içerik analizinin ardından birçok disiplini kapsayan ve bu disiplinler arası geçişliliği mümkün kılan söylem analizinin temel varsayımı, bir metnin sosyal bağlama göre şekillenmesi durumudur (Van Dijk, 1985). Dolayısıyla, bir toplumsal cinsiyet kuruluşu olarak annelik durumunun, pratikte karşılıkları bulunan kültürel kodlarını ve bu simgesel kodların medya metinlerine yansımalarını görebilmek mümkün hale gelmektedir. 
$\mathrm{Bu}$ çalışmada feminist yazının ortak eleştirel perspektifine dayanarak reklamlarda üretilen annelik temsili ve bu metinlerde yer alan annelik söylemini görünür kılmak amaçlanmaktadır. Bunun için, bu çalışma kapsamında, son beş yıl içinde mücevher, teknolojik ev aletleri, sigorta ve kargo olarak belirlenmiş dört kategorideki yedi markanın anneler günü kampanyaları kapsamında her bir kategori için web ortamında elektronik olarak üretilen iki ve toplamda sekiz adet internet reklamının ürettiği annelik söylemi incelenmektedir.

Çalışma kapsamına bu dört kategorinin dahil edilmesinin çeşitli nedenleri vardır. İlki, seçilmiş olan reklam materyallerinde teknolojik ev aletleri ve mücevherlerin anneler günü kampanyalarında ön plana çıkarılan ve anneler günü için tercih edilen hediyeler kapsamında üst sıralarda yer almasının toplumsal cinsiyete dayalı arka planına eleştirel bir bakışla yaklaşmaktır. İkincisi ise sigorta ve kargo hizmetleriyle ilgili reklamlarda annelik olgusunun işlevsel bileşenlerini oluşturan doğurganlık ve koruma içgüdüsü gibi temel kavramların tercih edilmesinin toplumsal karşılıklarına vurgu yapmaktır.

Çalışmanın yöntemsel izleği çerçevesinde reklamlarda kullanılan görsel ve yazılı materyallerde yer alan anlam ve söylemin eril siluetine işaret edilmektedir. Bu kapsamda yanit aranacak sorular, "reklamların annelik kurgusunun toplumsal inşası sürecinde nerede konumlandırılabileceği", "reklamlardaki annelik mitinin ne tür toplumsal cinsiyet temelli karşıtlıkları beslediği" ve "markaların ürün ve hizmetinin satışını artırmak amacıyla internet reklamlarında nasıl bir annelik inşası sunduğu"dur.

\section{Annelik ve mücevher ilișkisi üzerine: Atasay ve Gülaylar reklamları örneği}

Mücevher ve takı kullanma geleneği, modern toplumdaki tüketim pratikleriyle birlikte düşünüldüğünde, kadın bedeninin, toplumsal cinsiyet pratiklerine uygun ve göze hitap edecek bir şekilde bakımlı olması ve aksesuarları üzerinde bulundurması ile anlam kazanmaktadır. Fakat diğer yandan bu durum, kadın bedenini, beden üzerindeki meta ile birlikte bir tüketim nesnesi haline getirmektedir. Bu varsayımı anneler günü kampanyalarında yer alan annelik metaforunun kullanımıyla birlikte düşündüğümüzde de benzer bir durum ortaya çıkmaktadır.

Atasay markasının anneler gününe için yazılı basında yer alan "Beştaş Pırlanta Alyansa Tektaş Hediye" sloganlı reklam kampanyası (Reklam 1), tüketim alışkanlıkları üzerinden inşa edilen bir annelik kurgusunun yeniden 
üretimi konusunda bize çokça ipucu sunacak niteliktedir. Reklamdaki görsel incelendiğinde, "beştaş" mücevherinin, tektaş üzerindeki pırlantadan beş tanesini bir araya getiren "göz dolduran" bir dizayna sahip olma ve yüksek ekonomik değer taşıma gibi bir takım çağrışımlarla bezendiğini söylemek mümkündür. Reklam metninde yer alan "alyans" ve "tektaş" kavramları evlilik yapan ya da bir evlilik planlayan kadınlar ile ilgili olarak simgeleştirilmiş ürünlerdir. Dolayısıyla her iki ürün de doğrudan evliliği ve sonrasını akla getirmektedir. Evlilik sonrasında potansiyel olarak gerçekleşmesi beklenen annelik durumunda ise aynı takılar, evlenirken bu mücevherlere sahip olmayan kadınların anne olduklarında kesin olarak sahip olmaları gereken bir çerçeveye bürünmektedir ve böyle bir alt anlamla kampanya içerisinde sunulmaktadır. Tüketim kalıpları içerisinde bu klişe süreç oldukça sık vurgulanmaktadır. Tolungüç'ün (1999, s.117) tüketim ve simgesel anlatım ilişkisinin reklamlar üzerinden kurulduğu, burada yer alan sembollerin klişe davranış kalıplarıyla paralellik gösterdiği ve psikolojik bir takım süreçlere seslendiğine yönelik vurgusu önemlidir. Klişe davranış kalıpları içinde toplumsal cinsiyet rolleri ve kalıp yargılar da yer almakta, annelik durumuna ilişkin olarak metalarla kurulan gerekçelendirilmiş ilişkisel bağlar da bu çerçeveye yerleşmektedir.

Reklam metninde en yukarıda yer alan “Unutulmaz bir Anneler Günü için" yazısı, öncelikli olarak bir anne veya potansiyel bir anne adayı olarak kabul edilen kadının, tektaş veya beştaş gibi toplumsalda belirli karşılıkları bulunan takılara sahip olmasının gerekliliğini vurgulamaktadır. Ayrıca toplumsal cinsiyet kurgusu içindeki rol ve kalıp yargıların beraberinde getirdiği sembolik çağrışımlardan hareketle belirli bir ekonomik göstergeye işaret etmekte ve "öteki"nin sahip olması nedeniyle kendisi için de bir ihtiyaç haline gelmektedir. Daha da önemlisi reklamdaki takılar aynı zamanda ailenin diğer bireylerinin "annelik" niteliğinden ötürü "anne olan kadın"a verdiği değerin bir ölçütü haline getirilmektedir. Böylece reklam metninde yer alan ürün, soyut değerlerin somut bir karşılığı olarak meşrulaşmaktadır. Böyle bir kampanyayla hem beştaş hem de tektaş sahibi olan her annenin, anneler günü "unutulmaz" kılınmaktadır.

Reklamda yer alan görselde, siyah zeminde kırmızı oje metaforuyla öne çıkan bakımlı eller ve sözü edilen beştaş ve tektaş takıları yer almaktadır. Görsel bu bakımdan modern annelik kurgusunun genç olma ve bedenine özen gösterme gibi bir takım anlamsal karşılıklarını da üretmektedir. Fakat gündelik yaşamları belirlenmiş ve baskıcı emek süreçleriyle örülen kadınların sürdürdüğü temizlik, yemek ve çocuk bakımı gibi ev içi görünmeyen emek 

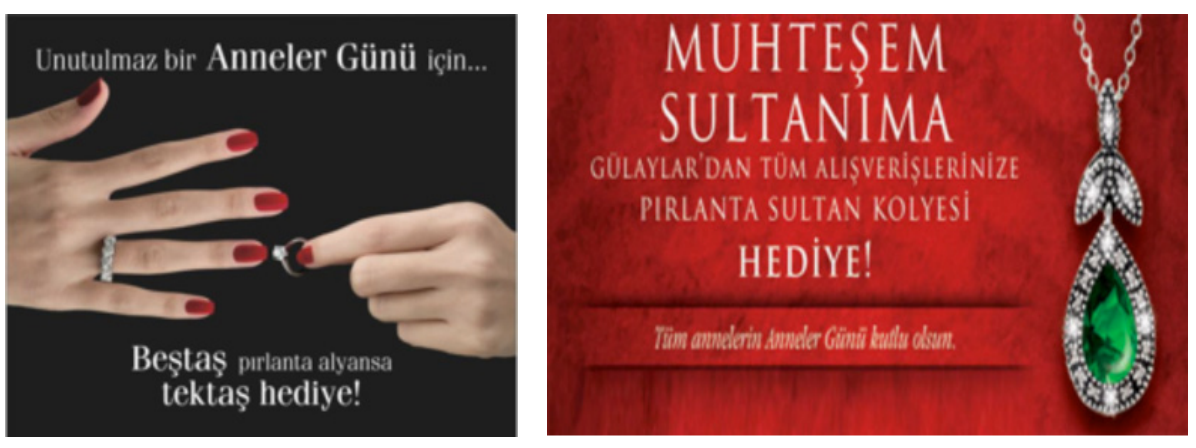

Reklam 1: Atasay

Reklam 2: Gülaylar

pratikleri, oldukça zaman alan, yıpratıcı ve bedensel çaba gerektiren işlerdir. $\mathrm{Bu}$ noktada görselin verdiği mesaj, modernliğin yüceltildiği bir toplumsal beklentiye dönüştürülmektedir: "annelik" ve "ev hanımlığı" bitiştirmesinin ve "emektar anne" figürünün yerini takı ürünlerinin reklamlarında oldukça sık kullanılan, bakımlı, genç ancak ev işlerine, çocuklarına ve kendine zaman ayırabilen "modern anne" figürü almaktadır.

Reklam metninindeki dikkat çekici ayrıntılardan bir diğeri, "Anneler için pek çok hediye seçeneği sizi bekliyor" yazısıdır. Anneler günü kutlama pratiği, günümüz tüketim toplumunu var eden tüketim kültürünün zihinlere yerleşmesi ile birlikte, bir tüketim stratejisi olarak, somut, simgesel ve maddi karşılığı bulunan ve popüler olan bir hediye alma zorunluluğu ile aynı anlama gelmektedir. Anneler gününü unutulmaz yapacak olan hediyelerden de kuşkusuz bu nitelikleri taşıması beklenmektedir. Bu "ihtiyacı" karşılayabilecek, bir başka deyişle benzer kodları oluşturabilecek ürün çeşitliliğinin bulunduğu bilgisine de reklam metninden ulaşabilmek mümkündür.

Reklam metninden hareketle, tektaş sahibi olma pratiğine ilişkin olarak değinilmesi gereken önemli bir başka nokta, tektaş gibi, tüketim kültürünün beraberinde getirdiği yapay ihtiyaçlara karşılık gelen sembolik metaların bizzat kadınlar için de arzu nesnelerine dönüşmesi/dönüştürülmesi durumudur. Pek çok popüler kültür ürününde tektaş, evlilik ve bağlılık gibi temalarla kodlanan, her kadının hayalini kurduğu, ulaşılması zor; fakat kadının özveriyle yapıp ettikleri sonucu "hak ettiği bir ürün veya kadınlara verilen değerin önemli bir göstergesi” olarak kurgulanmaktadır. 
Reklam metninde dikkat çeken bir diğer nitelik, ödemeye ilişkin kart bilgileri ve taksit seçenekleridir. Anlaşmalı bankanın ismi ve ödemeye ilişkin avantajlara reklamda yer verilmiştir. Reklamın bu bölümünün özellikle erkeklere yönelik bilgiler içerdiği görülmektedir. Çünkü ürünlerin ekonomik değerlerinin yüksek olması, bir "eş" ya da "baba" olarak erkeğin bütçesi dahilinde gerçekleştirebileceği bir alımı beraberinde getirmektedir. Markanın adı, reklam üzerinde diğer metinlerin karakter büyüklüğü ile kıyaslandığında çok daha kalın ve büyük harf karakterleri ile ödeme bilgilerinin bulunduğu yerin hemen üzerine konumlandırılmıştır. İlk bakışta dikkat çeken kelimeler, "Anneler Günü", "Beştaş”, “Tektaş”, "Atasay" ve "World” olarak ifade edilebilir. Bu kelimeler aynı zamanda, ürüne dair genel bilgi hakkında da fikir vermektedir. Söz konusu reklamdaki annelik kurgusu, tanıtımı yapılan ve taksit imkanlarından söz edilen bir tüketim nesnesi ile iç içe geçmiş biçimde sunulmuştur.

Anneler günü kampanyalarına yönelik bir diğer reklam metni, Gülaylar markasına aittir. (Reklam 2) Bu reklamda dikkatimizi farklı bir kurgu çekmektedir. "Muhteşem Yüzyıl" dizisinde yer alan değerli taşlar, zümrüt rengi, gösterişli giyim ve takı geleneği ve sultanlık gibi çeşitli metaforlarla, söz konusu dizi ile bu diziyi izleyen kadınlar arasında çağrışıma dayalı bir ilişkisellik kurulmaya çalışılmaktadır. Kırmızı fon üzerine, Muhteşem Yüzyıl dizisinin jeneriğinde kullanılan yazı karakterleri ile "Muhteşem Sultanıma" yazısı yazılmıştır ve söz konusu marka ürünlerine yönelik yapılacak alışverişlerde "Pırlanta Sultan Kolyesi" nin hediye olduğu belirtilmektedir. Geleneksel toplumsal kodlara karşılık gelecek şekilde, sultanlık, annelik durumuyla bitiştirilen ve sıklıkla tercih edilen benzetmelerden önemli bir tanesidir. Bu ifade, belirli bir yaşa erişme, annelik bilgi ve tecrübesinde olgunlaşma gibi bir takım anlamları da içermektedir. Reklam metniyle birlikte düşünüldüğünde, Muhteşem Yüzyıl dizisindeki geleneksellik, tecrübe, yıllara bağlı bir değer kazanma metaforları hatırlatılmakta ve anneliğin kendisi, sultanlık simgesi ve değerleri ile "taçlandırılmakta" dır.

Reklam görselinde, kampanya kapsamında hediye edilecek olan kolyeye yer verilmiştir. Bu görselin dikkat çekici yanı, ana kadın karakter olan Hürrem Sultan'ın dizi sırasında çokça kullandığı zümrüt taşlı takılardan bir tanesinin seçilmiş olmasıdır. Ayrıca yine diziyi göz önünde bulundurarak, bu değerli taşların bizzat padişahın kendi el emeğiyle işlenerek hazırlanması, dolayısıyla kadınlara sunulacak bir hediye için erkeğin emek vermesi metaforunun ön plana çıkarılması ve bununla birlikte hediyenin paha biçilemezliğinin 
vurgulanması ve bu hediyeyi sunan bir erkeğin padişahlık nitelikleriyle yüceltilmesi gibi birçok farklı anlamsal karşılığının bulunduğu çıkarımını yapmak mümkündür. Hall (1980, s.129) medya iletilerinin üretim ve tüketimini, üretim pratikleri, kuramsal bilgi, tarihsel ve teknik beceriler, tanımlananlar ve varsayılanlar üzerinden temellendirdiği yeniden üretim kavramıyla birlikte değerlendirmektedir. Bu çerçevede, kadınların ve annelerin bu dizi izleyicileri arasında önemli bir potansiyel çoğunluğu oluşturduğunu ve söz konusu reklamda dizide ilgi çeken ve beğeni kazanan kodların oluşturduğu çağrışımdan yararlanıldığını söylemek mümkündür. Böylece, dizide geleneksel olanı vurgulayan, görmüş geçirmiş, "sultan anne" imgesi, yine dizide çokça revaçta olan zümrüt kolye promosyonuyla birlikte kampanya dahilinde bir satış arttırma stratejisi olarak değerlendirilebilir. Bununla birlikte, ürünün, kampanya promosyonu olarak verilmesinin satış arttıran bir konsept olarak kullanıldığı görülmektedir. Bu noktada, anneye ve anneliğe verilen değerin bir karşılığ1 olarak değerli taşlardan oluşan pahalı takıların hediye edilmesi üzerine inşa edilen bir hediye kültüründen bahsetmek mümkündür. Metnin sonunda yer alan, "Tüm Annelerin Anneler Günü Kutlu Olsun" yazısı da reklamın bütünü itibariyle düşünüldüğünde, bir tebrik ifadesinden ziyade, annelik durumuna değer atfetme noktasında, söz konusu markanın ürünlerinden satın alınması veya hediye edilmesi ile "yegane sultan anne" ve bu ürünlerin alınmaması durumunda ise "diğer anne" kategorilerini meydana getirerek kutuplaştırmaktadır. Bu anlamda annelik durumun toplumsal kodlarından, tüketim kültürünün bir parçası olarak, işlevsel ve simgesel düzeyde meta tüketimine yönelik yapay ihtiyaçların oluşturulması için yararlanıldığı görülmektedir.

\section{Annelik ve teknolojik ev aletleri ilișkisi üzerine: LG ve Makro reklamları örneği}

Feminist literatürde yer alan kamusal alan ve özel alan tartışmaları içerisinde kadının ev içi görünmeyen emeği üzerinde uzun süredir önemle durulan bir konu olarak karşımıza çıkmaktadır. Çünkü özel alanla ilişkilendirilen kadınlık durumu, ev içi yeniden üretim sürecine dâhil olan tüm bedensel ve duygusal faaliyetlere yönelik, doğallaştırılmış, sistematikleştirilmiş, hiyerarşik bir cinsiyet ve toplumsal cinsiyet eşleştirilmesine tabi tutulmaktadır. Patriyarki ve toplumsal cinsiyet örüntülerinin kurgusal işleyişi ile paralel olarak, toplum içerisinde düzenleyici ve işlevsel özellikleriyle ön plana çıkarılarak edilgen kılınan ve ikincilleştirilen kadınlık durumu; annelik, merhamet, eve bağlılık ve fedakârlık gibi kavramlarla özdeşleştirilmektedir. Bu noktada, kadınlık durumunun önüne geçirilen bir annelik durumu belirginleşmekte, 
edilgen ve ikincil kılınmasının üzeri bu kılıfla örtülmekte ve kadının, anne olma potansiyeli üzerinden, özel alanda ev içi görünmeyen emek ve bağımlı kılındığı diğer sorumluluklar temelinde toplumdaki rol ve kalıp yargılar inşa ve yeniden inşa edilmektedir.

Hedef kitleye göre görüntüsünde değişiklikler olsa da evli ve anne kadın sunumu genellikle o ülkenin kültür, gelenek veya değerlerine en uygun davranışları gerçekleştiren ve bunu korumaya çalışan bir yapıda hazırlanır. Genellikle temizlik ürünleri ya da ev aletleri reklamlarında bu modeldeki kadınlar yer almaktadır. Ev işlerinden anlayan, evi ailesi ve çocukları için en iyiyi bilen kadın modelinin yer aldığı reklamlarda ürüne hizmete yönlendirme, bir erkek diş sesi tarafından ya da tavsiyede bulunan ve bilgilerini anlatan bir başka kadın modeli yer alır (Elden vd. 2011, s.544).

Ev işlerinin kendisi, özel alana ilişkin bu tür sorumlulukların başında gelmektedir. Kadınların vaktinin büyük bir bölümünü bu işlerin yapılmasına harcaması, teknolojinin ve bu teknolojiyle üretilen ev aletlerinin de zaman ve emek tasarrufu sağlamaya yönelik bir seyirde ilerlemesini beraberinde getirmiştir. Fakat buradaki esas sorun, gerek toplumsal pratiklerde gerekse bunun bir uzantısı olarak medya metinlerinde yapısal olarak ev içi emeğin sorumluluk ve görev yükünün yalnızca kadınlık durumu üzerinden sürdürülmesidir. Söz konusu metinlerde, gelişen teknolojinin pratik oluşu, hızı, zaman ve emek tasarrufu sağladığı vurgulanmakta; fakat kadınların görünmeyen emeğine dikkat çeken veya ataerkinin özel alan içerisindeki emek süreçlerinin üzerinde kurduğu baskıcı düzene yönelik eleştirel bir farkındalık bulunmamaktadır. Bu durum aynı zamanda, babalar günü reklamlarında onlara hediye edilebilecek ve onlara yönelik olarak ev işlerinin yapımını kolaylaştıracak herhangi bir teknolojik ev aleti kampanyasının "tuhaf" veya "gülünç" karş1lanmasını da açıklamaktadır. Anneler gününe yönelik teknolojik ev aletleri reklam kampanyalarının metin ve görselleri incelendiğinde, zamandan tasarruf sağlayarak çocuklarına vakit ayırabilme, fedakârlıklarla ailenin hayatını kolaylaştırma ve her sorumluluğunu yerine getirerek bir zaman yönetimini sağlama klişelerine sıklıkla yer verildiği görülmektedir.

LG markasının anneler günü kampanyası reklam metnini, yukarıda belirttiğimiz nitelikler üzerinden okumak mümkündür (Reklam 3). Reklam içerisinde süpürge, mini fırın ve bulaşık makinesi gibi yemek ve temizlik yapımında kullanılan teknolojik ev aletlerine yönelik indirimler "anneler gününe özel” bir kampanya ile sunulmaktadır. Reklamda ön plana çıkan görselde anne ve kızının mutlu bir yüz ifadesi ile birbirlerine sarıldıkları görülmektedir. Anne, genç ve bakımlı bir görüntüye sahiptir. Ayrıca kendi üzerinde ve 


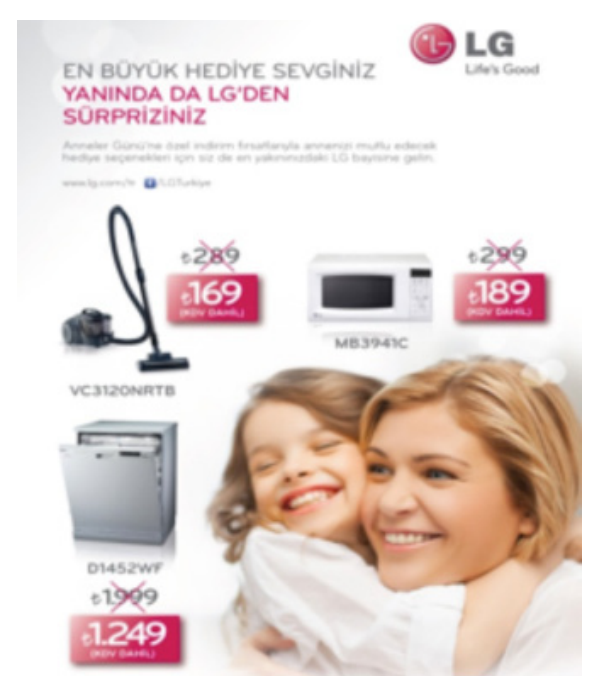

Reklam 3: LG

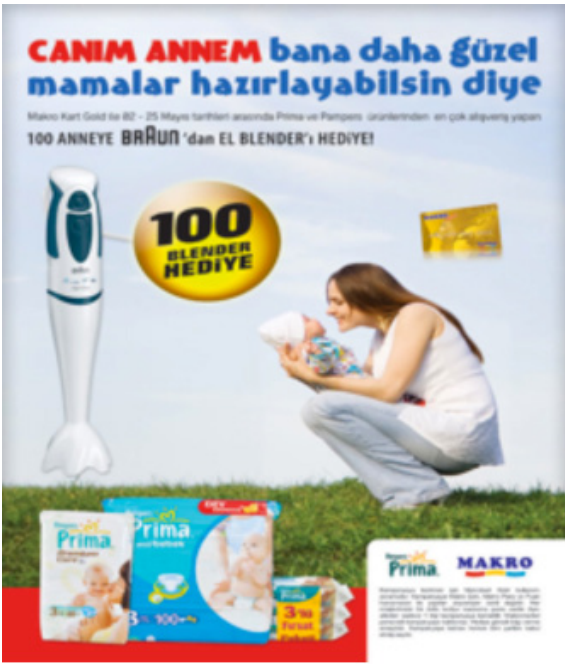

Reklam 4: Makro Market

çocuğunun üzerinde temizlik ve hijyenin sembolü beyaz giysiler bulunmaktadır. Dolayısıyla ilk bakışta reklamda, söz konusu markaya ait teknolojik ev aletlerini kullanarak ev işlerini kısa sürede tamamlamış bir annenin, kalan zamanını çocuğuna ayırarak oluşturduğu mutluluk tablosu kurgusu dikkat çekmektedir. Anne sevgisi ve mutluluk kavramlarına özellikle teknolojik ev aletleri reklamlarının metinlerinde ve görsellerinde çokça başvurulmaktadır. Bu tespiti reklam metninde yer alan, "En Büyük Hediye Sevginiz Yanında da LG'den Sürpriziniz" şeklinde belirtilmiş bir slogan da desteklemektedir. Aynı reklamın alt metni toplumsal cinsiyet açısından eleştirel bir perspektifle değerlendirildiğinde, markanın sunduğu ucuz ev aletlerinin anneler için bir fırsat olduğu, çünkü ürünlerin teknolojik içeriğinin ev işlerinin tamamlanmasını hızlandırdığı ve bir annenin çalışma yaşamı ve çocuk bakımı türünden diğer sorumluluklarına da vakit ayırabilmesini kolaylaştırdığı gibi okumaları yapmak mümkündür. Dolayısıyla annelik, kadınların özel alan şeklinde tanımlanan bir mekânsal kurgu içerisinde yapıp ettiği faaliyetlerle birlikte adeta bir "mesai" haline dönüşmektedir; fakat popüler kültür ürünleri içerisinde bu noktanın üzeri örtülerek, kadınların anne olmalarından daha önemli herhangi bir şeyin olamayacağını vurgulayan kutsal annelik miti pekiştirilmektedir.

Metinde yer alan "annenizi mutlu edecek hediye seçenekleri" ifadesi de annenin mutlu olma durumunu ev işlerinin yapımını kolaylaştıran teknolojik ev aletleriyle eşleştirmektedir. Fakat diğer yandan "sürpriz" olarak nitelendirilen bu ürünler, kadınların toplumsal varoluşlarının kurgusal te- 
mellerini doğallaştıran, kadın olarak özgün varoluşlarının ise gölgelendiği bir mekanizmanın işlevsel parçalarını oluşturmaktadır.

Aynı kategori içerisinde örnek olarak verebileceğimiz ikinci internet reklamı Makro Market'in anneler günü kampanyasıdır (Reklam 4). Reklamda, yeşil renk ve doğa çağrışımının kullanıldığı bir arka fon görüntüsü ile anne ve bebeğinin mutlu bir fotoğrafına yer verilmiştir. “Canım Annem bana daha güzel mamalar hazırlayabilsin diye" sloganı ile Makro marketlerden bebek bakım ve temizlik ürünlerinden en çok alışverişi yapan anneye bir markanın el blenderi hediye edilmektedir. Burada da daha önce bahsedildiği gibi görünmez bir anne-kadın emeğinin reklam kurgusu içerisinde doğallaştırıcı bir kabulle oluşturulduğu görülmektedir: reklamda anne, bu sorumlulukları kabul etmiş, içselleştirmiş ve en önemlisi bu görevleri yerine getirmekten mutluluk duyar bir şekilde gösterilmektedir.

Bu kampanya kapsamında kadının özel alanla eşleştirilen annelik kalıp yargılarını tanımlayan yemek yapma ve çocuk bakma rollerine yer verilmiştir. Medya metinlerindeki annelik temsili, kadınlık durumuna ilişkin toplumsal cinsiyet rollerinin, fizyolojik cinsiyetle ilişkilendirilerek doğallaştırılmasına katkıda bulunmaktadır. Bunun da ötesinde, kampanya, kadının birey olarak var olabilme kapasitesi ve iradesini görmezden gelerek, aile içinde, yemek, bakım, temizlik gibi süreçleri ve aynı zamanda manevi ihtiyaçları karşılayan cinsiyetsiz bir ihtiyaç giderici nesne olarak yeniden üretimine zemin oluşturmaktadır. Bu da feminist bakışın öngördüğü birçok sorunsalı dışarıda bırakarak yapısal dinamikleri silikleştirmekte ve normalleştirilene yönelik eleştirel değerlendirme yapmayı güçleştirmektedir.

\section{Sigorta reklamlarında anneler günü kampanyalarının sunumu: Anadolu Sigorta reklamları örneği}

Sigortacılık alanındaki gelişmeler, sosyal devletin ve kamu yararını başat kabul eden politikaların terk edilmeye başlanması, bunun karşısında neoliberal politikaların ve özel sektör hizmetlerinin yükselişe geçmesiyle eğitim sağlık gibi alanların özelleştirilmesini de içeren bir dönüşüm içerisinde ele alınmalıdır. Üretimin hayati birimi olarak ailenin ve mülkiyetin korunması gereği, özel sektöre devredilen bir görev olarak belirmektedir; dolayısıyla bu koruma gereği, "korunmaya muhtaç" bir kesimin oluşturulması zorunluluğunu da beraberinde getirmektedir.

Sigorta reklamlarının temel vurgusu, bireyin veya sahip olduğu mülkiyetin güvenli bir biçimde teminat altına alınmasıdır. Dolayısıyla "güvenlik 

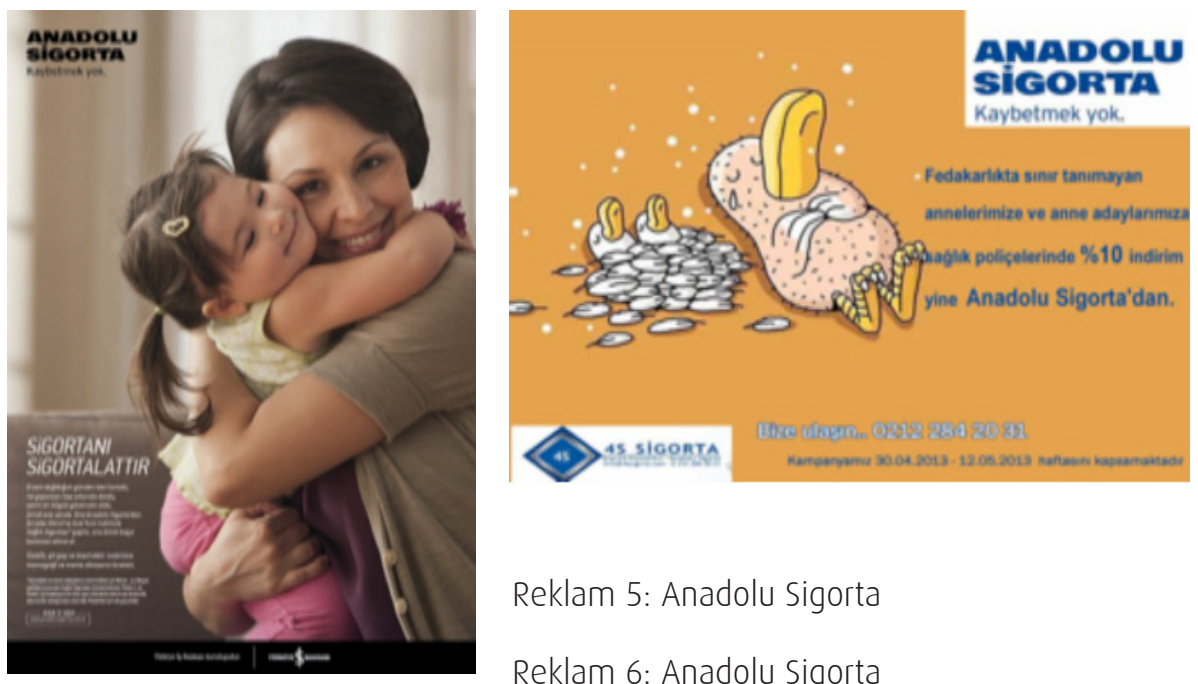

Reklam 5: Anadolu Sigorta

Reklam 6: Anadolu Sigorta

güvencesi verme" yi amaç edinen bir kampanya örüntüsü bu tür reklamlarda sıklıkla tercih edilmektedir. Bununla birlikte sahip olunan maddi kaynakların, mülkiyetin veya bireylerin kendilerinin sigorta kapsamında alınmasının ön koşulu, bu kişilerin ya da kaynakların "değerli” bulunmasıdır. Dolayısıyla belirli kategorik sınıflandırmalar içeren değer ölçütü, aynı zamanda sigortalanacak olanın güvenliğinin de teminatı haline gelmektedir.

Anadolu Sigorta markasının bu kapsamda düzenlediği anneler günü kampanyasındaki internet reklamı incelendiğinde, markanın hemen altında yer alan "kaybetmek yok" ifadesi ve diğer reklamlarda da sıklıkla karşılaşılan anne ve çocuğun birbirlerine sarıldıkları mutluluk tablosu görseline yer verildiği görülmektedir (Reklam 5). Reklam metninde yer alan “Sigortanı Sigortalattır" sloganı ile anne, çocuğunu dünyaya getirdiği andan itibaren doğal bir koruma içgüdüsü ile çocuğunu karşılıksız bir sevgiyle koruyan ve destekleyen bir "sigorta" olarak tanımlanmakta ve zaman içerisinde de annelerin daha da önemlisi anneliğin sürdürülmesi adına sigortalattırılarak güvence altına alınmasının gerekliliği hatırlatılmaktadır.

Baudrillard (2004, s.172) bedenin bir metaya dönüşme sürecini sağlık, gençlik, tedavi kültürü, perhiz, zariflik gibi kavramlarla ve bu kavramların bedeni kuşatan bir arzu söylemine yaptığı vurguyla değerlendirmektedir. Dolayısıyla annenin yaşının ilerlemesi, anne üzerinden düzenlenen çeşitli ekonomik dinamiklerin sürdürülmesi noktasında nesnelleştirilen bir beden sağlığı ihtiyacını ve bu ihtiyaçların karşılanmasına yönelik yapay gereklilikle- 
ri beraberinde getirmektedir. Anneler günü kapsamindaki sigorta reklamları da güven ve teminat hissiyatını anne-çocuk ilişkisindeki katışıksız ve karşılıksız güven temini ile birleştirmektedir. Metnin sonunda, "onu ömür boyu koruman altına al" yazısı ile de bu bağlam kuvvetlendirilmektedir.

Görselde kullanılan annenin sağlıklı ve güçlü görünümüne karşın, söz konusu sağlık sigortasından yararlanması gereken bir orta yaş imgesiyle temsil edildiği görülmektedir. Görselde ayrıca çocuğuna sıkıca sarılma metaforu, annenin çocuğunu her durumda fedakârlık, sevgi ve şefkat ile koruyarak destekleyeceğinin güvencesini çağrıştırmaktadır. Burada söz konusu mülklerini güvence altına almak isteyen müşterilere sunulacak hizmetin güvencesi, görseldeki çocuğun kendisini güvenle ana kucağına teslim etmesi ile ilişkilendirilmektedir. Dolayısıyla bu reklamdaki annelik kurgusuyla marka, hem kendi güvenirliğini hem de annelikle eşleştirilen "karşılıksız ve sonsuz güvenlik sağlayan sigorta" tasvirini yeniden üretmektedir. Buna ek olarak, toplumsal cinsiyet anlatısının önemli bir bölümünü, kadının anne olduktan sonra içgüdüsel olarak, her koşulda ve her alanda çocuğuna güvenli bir ortam sunma, onu yetiştirme, fiziksel ve duygusal olarak bu süreci merkeze alan bir hayat sürdürme, kendine dair yapmak istediklerinden de annelik görevleri oranında feragat etme gerekliliği söylemini oluşturduğu görülmektedir. Dolayısıyla söz konusu banka ve bünyesinde bulunan sigortacılık alt kolu da, bu kanıksanmış toplumsal cinsiyet söyleminden yola çıkarak, kendi markasının sunacağı güven ve sigorta niteliğini, kendisinden hiçbir zaman kuşku duyulmayacak bir güven ortamı sunan "fedakâr güvenli anne" miti ile kurgulamaktadır. Bireysel varlığı görünmezleştirilmiş işlevsel annenin sigorta ile "koruma altına alınması" ise, aynı zamanda kendi yeniden üretiminin sigortası olma durumuna karşılık gelmektedir.

Anadolu Sigorta'nın bir başka internet reklamında yine "kaybetmek yok" başlığı altında tanımlanan annelik kodlarının kalıtsal, verili, doğal ve kaçınılmaz bir gerçeklik olduğu söylemi güçlendirilmektedir (Reklam 6). Bu reklamda da "fedakâr anne" metaforu doğal yaşamın bir parçası olan anne kuşun, üzerlerine kar yağan yavrularının üşümemesi için, kendi bedenine ait olan tüylerini yavrularının üzerine örterek çocuklarının ısınması fakat kendisinin üşümesi gibi bir görselle betimlenmektedir. Bu durum annenin ne pahasına olursa olsun ailesi ve çocuklarının sağlıklı ve güvenli bir hayat sürmesi adına kendisini "feda" ettiği, bununla birlikte adanmış annelik varoluşunun yüceltildiği ve kadınlara ilişkin kaybedilen bireysel varoluş ve gerçekleştirilmek istenen kişisel hedeflerdeki başarısızlıkların ise ikincil değerler olarak kaldığı bir tabloyu ortaya çıkarmaktadır. 
Görselde belirtilen ne pahasına olursa olsun "anneye atfedilmiş fedakârlık" reklam metninde de kuvvetlendirilmektedir. Fedakârlıkta sınır tanımayan anneler ve anne adaylarına yönelik olarak sağlık poliçelerindeki indirimin kendisi bir anneler günü hediyesi olarak sunulmaktadır. Burada sıklıkla vurgulanması nedeniyle altının çizilmesi gereken durum, gündelik pratiklerde de annelik durumunun bu türden ön kabullerle kanıksanmış olmasıdır. Sosyalizasyon ve kültürel sermaye olarak adlandırılan birikimsel süreçlerle bu gruba dâhil olacak potansiyel anne adaylarından da, görseldeki kuş metaforundan hareketle kendine ait parçalarından vazgeçerek, kendini anne olarak bir aile içerisinde var etmesi beklenmektedir. Çünkü ancak bu sayede ve bu özveriyle toplum tarafından kabul görebilecektir.

Burada bir noktaya daha dikkat çekmek gerekmektedir. Söz konusu sigorta markasının anneler günü kampanyası kapsamında sunulan hediye, sağlık alanındadır. Fakat bunun haricinde söz konusu markanın bünyesinde, sahip olunan maddi bir takım varlıklara sigorta yapılması, emeklilik programları ve daha birçok çeşit sigorta türü mevcuttur. Fakat genellikle emekliliğe ilişkin alternatif imkanların tanıtıldığı reklamlar çalışan bireylere ve özellikle de çalışan erkeklere yönelik olarak kurgulanmakta, bu tür reklamlarda kadınların söz konusu imkanlardan yararlanabileceği en uygun durum, ancak bir "aile içerisinde olma" vurgusu ile çerçevelenmektedir. Dolayısıyla anneler günü kapsamında kadınlara ait bir mülkiyetin sigortalanması veya ev kadınlarının bireysel emekliliğe yönlendirilmesi gibi bir kurgu seçilmemiştir. Çünkü böyle bir kurgu, kadının aile içerisindeki ekonomik varlığını inşa edebilme potansiyelini taşımaktadır. Oysa tercih edilen anne imgesi hâkim toplumsal cinsiyet söyleminden hareketle, aile içerisinde kendisine sunulanlar üzerinden araçsal olarak betimlenen görece bir değerle ve daha çok işlevsel rol ve görevleriyle ön plana çıkartılmaktadır. Yaşı gerekçesiyle sağlığı ve dolayısıyla işlevselliği tehlikededir, bu yüzden yeniden üretiminden sorumlu tutulduğu aile tarafından korunması ve denetlenmesi gerekmektedir.

\section{Kargo reklamlarında anneler günü kampanyalarının sunumu: Sürat Kargo ve Aras Kargo reklamları örneği}

Anneler günü reklam kampanyalarında farklı sektörler annelik durumuna ilişkin farklı toplumsal cinsiyet rollerini ön plana çıkarmakta; fakat tamamı anneliğin toplumda yüceltilen değerlerini yeniden üretmesi yönüyle ortaklaşmaktadır. Annelik kurgusunun incelediğimiz kargo reklamlarında öne çıkan metaforu doğurganlık ve hamileliktir. Bu metaforların sunum biçimi ise, 
"annelik yaşamayanın bilemeyeceği bir duygudur" şeklinde sloganlaştırılabilecek bir alt anlam ile metne yerleştirilmektedir. Bu ifade önemlidir, çünkü altı çizilmesi gereken bir ikilemi oluşmaktadır. Anne olma mertebesine ulaşmış kadınlar "kutsallaştırılmakta" ve yüceltilen annelik miti pekiştirilmekte; bu mertebeye erişememiş kadınlar ise bir takım toplumsal dışlama ve itibarsızlaştırma mekanizmalarına maruz kalmaktadırlar.

Reklamlardaki dikkat çekici bir diğer unsur, kampanya dâhilinde indirim yapılacak ya da ön plana çıkartılacak olan ürün veya hizmetin niteliklerinin, toplumsal yaşama doğrudan temas eden, toplumca kabul gören ve özel bir yere yerleştirilmiş bulunan değer veya faaliyetler ile bitiştirilerek tüketim sürecinde dolaşıma sokulmasıdır. Williamson'un vurgusuyla "Reklamın açık işlevi şeyleri bize satmaktır". Bu nedenle ürünlerin, fiziksel görünüşleri ve esas işlevlerinin ötesine geçen bu ürünün kullanıcı için ifade ettiği bir anlam ve "değişim değeri” söz konusudur. "Reklam 'şeyler'in bu ifadelerini, insan ifadeleri olarak bize tercüme eder; onlara insani olarak bir simgesel değişim değeri verilir. Reklamlar, daha çok nesnelerin dilini insanların diline dönüştürebilen ve tersini yapabilen bir yapı oluşturur" (2001, s.12). İncelediğimiz iki kargo reklamı içerisinde de, annelik, doğurganlık ve bebeğin doğumdan önce belirli bir süre anne karnında özenle ve dikkatle taşınması gibi temalar, kargo taşıma hizmetinin de temel argümanlarını oluşturmaktadır.

Sürat kargo markasının anneler gününe yönelik olarak gerçekleştirdiği reklam kampanyasının internet reklamında yer alan görsel ve metin böyle bir çerçevede açıklanabilir. Söz konusu reklamda, bir anne ve omuzlarında taşıdığı bebeğin mutlu fotoğrafının temel görseli oluşturduğu, "Bazı Duygular Vardır Taşımayan Bilemez" sloganı ile birlikte, "Bizleri en değerli varlıkları olarak 9 ay taşıyan annelerimizin hediyelerini Anneler Günü'ne özel \%30 indirimle taşıyoruz." metni yer almaktadır (Reklam 7). Afişin sol alt kısmında markanın logo ve ismine yer verilmiştir. Sağ alt bölümünde ise markanın sponsorlukları ve iletişim bilgileri yer almaktadır. Reklam görselinde ayrıca, güven ve ferahlığı temsil eden bir gökyüzü, annenin sıkıca ellerinden kavramış olduğu yukarıya ve karşıya bakan gülümseyen bir bebek ve bu güvenin kaynağı olarak ileriye fakat yere bakan bir anne bulunmaktadır.

Annelik kurgusuna dair genel kabul görmüş süreç veya değerlerin belki de en önemlisi olarak nitelendirilmiş çocuk sahibi olma ve bu durumun beraberinde getirdiği başlangıç noktası olan hamilelik evresi, açık şekilde kampanya metninde hâkim şekilde ele alınan ve tanıtımın da bu pratik üzerinden gerçekleştirildiği bir örnek olarak karşımıza çıkmaktadır. Hamileliğin duygu- 


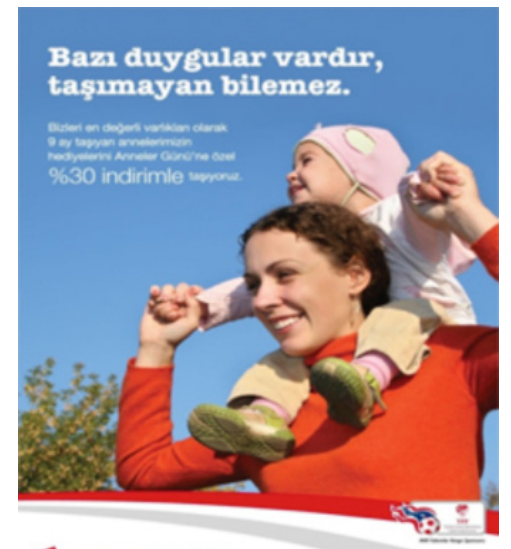

SURATKARGO

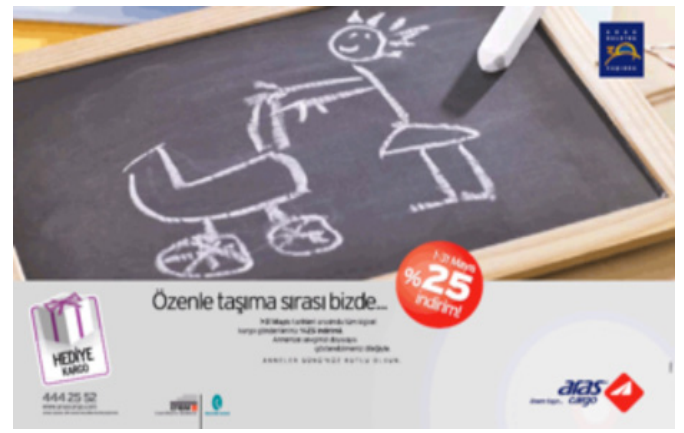

Reklam 7: Sürat Kargo

Reklam 8: Aras Kargo

sal değeri ön plana çıkartılarak eşsizleştirilmekte ve bununla kargo reklamının güvenli taşıma sloganı arasında bağlantı kurulmaya çalışılmaktadır.

Aras kargonun anneler günü kampanyasında yer alan internet reklaminı bu varsayımlardan hareketle okumak mümkündür. Söz konusu reklam alanının yaklaşık olarak üçte ikisini, bir yazı tahtasına tebeşirle çizilmiş bebek arabası ve anne görseli oluşturmaktadır (Reklam 8). Dolayısıyla annelik ve doğurganlık bu reklam içerisinde de gerek görsel gerekse metin düzleminde karşımıza çıkmaktadır. Görselden kalan üçte birlik bölümü kapsayan reklam metninde yer alan "özenle "aşıma sırası bizde" sloganı dikkat çekicidir. Çünkü yukarıda vurgulamış olduğumuz ve daha önceki reklamlarla da ilişkilendirebileceğimiz fedakâr, güvenilir ve işlevsel annelik simgeleri bir kargo reklam kampanyasının satış stratejisi için kullandığı simgelere dönüştürülebilmektedir. Kadının hamilelik sürecindeki özeni ve titizliği, kargo taşımacılık hizmetinin kalitesi ile bitiştirilmektedir. Diğer yandan reklamda, kampanya bilgileri ve belirlenmiş tarihler arasında yapılacak kargo işlemlerine yönelik indirimler yer almaktadır.

Özetle, her iki kargo reklamı anneler günü kampanyasında "güvenli taşımacılık" parolası ekseninde kadınlık ve annelik durumlarını homojenleştirerek bir potada eritmektedir. Bu kampanyalar içerisinde kadının sürekli biçimde anne olma potansiyeline vurgu yapılmakta ve anneye duyulan sevginin karşıl1ğı olarak çeşitli hediyelerin anneye taşınması şeklinde araçsallaştırılmış dolaylı bir hizmeti içermektedir. Dolayısıyla kargo hizmetinde annelik söylemi, kendisini “anneye, anne titizliği ile sevgi ulaştırma” işleviyle yeniden üretmektedir. 


\section{Sonuç}

Medya kurumunu meydana getiren araç ve metinlerin, eleştirel feminist teorinin temel tartışma alanlarından olan toplumsal cinsiyet temelindeki annelik kurgusunu, patriyarkinin hâkim paradigmasıyla oluşturması ve kullanması oldukça önemlidir. Çünkü bu aynı zamanda cinsiyet temelinde doğallaştırılmış toplumsal rol ve kalıp yargılara yönelik eleştirel bir sorgulamayı köreltmektedir. Reklamlarda temsil edilen annelik durumu, tüketim kültürünün gereklilikleriyle paralellik gösteren bir takım ortak kodlar içermektedir. Annelik durumunu betimlemek üzere üretilmiş toplumsal cinsiyet kodları, gündelik yaşama işaret eden somut çağrışımlar kurarak toplumsal değerleri tüketim pratikleri içerisinde dolaşıma sokmakta, yeniden üretmekte ve meşrulaştırmaktadır. Söz konusu alanlarda hizmet veren birçok markanın kampanyalarına dâhil etmiş oldukları ürün ve hizmetlerin seçimleri de tesadüfî değildir. Toplumsalda somut ve işlevsel karşılıkları bulunan ve bu değerler düzleminde annelik durumu ile ilişkisi kurulabilecek ürün ve hizmetler, reklam metinleri ve görselleriyle desteklenerek insansı bedenlere büründürülmektedir.

Söz konusu reklamlardaki mücevher kategorisi ve annelik durumu, annenin emeklerinin karşılığı olarak pahalı hediyeleri hak ettiği ve yaratılmış tecrübeli fedakâr bir "sultan anne" imgesinin memnuniyetinin ancak reklamdaki ürünün anneye hediye edilmesi ile sağlanabileceği gibi bir alt anlamlar bütünüyle izleyicilere ulaşmaktadır. Yüklü bir maddi karşılığı bulunan bu tür hediyeler, annelik durumuyla örtüşen toplumsal cinsiyet rol ve kalıp yargılarıyla paralellik göstermekte, anneden de bu ürünlerle kendisini yegâne, zengin ve mükâfatlandırılmış hissetmesi beklenmektedir. Aynı zamanda annelik durumunun reklamlardaki temsili, bu yöndeki bir tüketim alışkanlığı teşvikine de hem medya metinleri arasındaki çağrışımları kullanarak hem de buradaki ürünlere yönelik yapay ihtiyaçlar yaratarak yol açmaktadır. Mücevher reklamları ve annelik bitiştirmesi, evlilik öncesi ve sonrası süreçte de sürmektedir. Burada yükselen söylemin "sultan annelerin fedakârlıklarına biçilecek somut ve pahalı bir karşılık" ifadesiyle sloganlaştırılabilmesi mümkündür.

Teknolojik ev aletleri ve annelik ilişkisi üzerine geliştirilmiş reklam kampanyalarındaki söylemsel kuruluşu da "mutlu ev kadını" ve "hayatını pratikleştirerek ailesine zaman yaratan kadın" sloganlarıyla ifade etmek mümkündür. Çünkü buradaki vurgu, annelik süreci ile birlikte kadının ev işleri için ayırmakta olduğu zamanı kısaltmak; fakat bu süreyi çocuklarına daha fazla vakit ayırmak ve bundan kalan zamanda "aile ücretine katkı" ola- 
rak nitelendirilen bir işe devam etmek ön kabulünden beslenmektedir. Yeni teknoloji, kadınların işlerini bu anlamda kolaylaştırıyor gibi görünse de, toplumsal cinsiyet temelindeki baskılayıcı rollerde eleştirel ve alternatif farklılaşmaya yönelik bir çözümleme pratiği geliştirmekten oldukça uzaktır. Temizlik, mutfak ve çocuk bakımı gibi tek bir cinsiyetle özdeşleştirilen toplumsal roller, gelişen teknolojinin sunduğu pratik olanaklara karşın hala kadın ve annenin konumunu yeniden üretmenin pratik araçları olarak işlev görmektedir.

Sigorta reklamlarında ön plana çıkan annelik söylemi "anne ailenin sigortasıdır" ve "annenin korunması gerekir" gibi iki temel cümle ile özetlenebilir. Kampanya içerisinde annenin, ailenin koşulsuz ve sürekli güvenliği inşa eden bir sigorta işlevi ile bütünleştirildiği görülmektedir. Annenin zaman içerisinde yaşlanması veya yıpranması, annelik sorumluluklarını yerine getirememesine ve kendisinden beklenen güvence işlevinin sekteye uğramasına neden olma potansiyelini taşımaktadır. Dolayısıyla temel sağlık kontrollerini içeren sigorta hizmetlerine, anneler günü kampanyaları çerçevesinde öncelikle yer verilmektedir. Böyle bir reklam kurgusu içerisinde annelik temsili saf ve duygusal olarak kurulsa dahi bu yönüyle ele alınamayacak kadar tüketim alanına dâhil edilmiş ve annelik konumunun kendisini satış hedefleri altında ikincilleştirmiştir.

Kargo reklamlarıyla üretilen annelik söyleminin slogan cümlesi de "anne hassasiyetiyle taşımacılık" olarak ifade edilebilir. Kargo hizmeti, ürünlerin lojistik sürecini yürüten bir faaliyet alanını kapsamaktadır; fakat bu teknik süreç reklam kampanyalarında annenin hamilelik, doğurganlık süreçlerindeki titizlik ve hassasiyeti ile birleştirilmiştir. Böylece reklam kurgusu, toplumsalda yer bulan rol ve kalıp yargıları kendi ürün ve hizmetiyle uyumlaştırarak, gündelik yaşama ve bireye temas eden bir gerçekliğe dönüşmektedir.

Kategorik olarak anneler günü kampanyalarına yönelik hediyeler kapsamında ön plana çıkmış markalar, alıcı kitle üzerinde doğrudan veya dolaylı olarak tüketim alışkanlıklarıyla biçimlendirdikleri bir yaşam tarzını oluşturmayı amaçlamaktadır. Böyle bir hedefi gerçekleştirmenin teknik bir takım stratejileri kuşkusuz mevcuttur; fakat söz konusu yöntemlerden en yaygin ve tercih edileninin başında, toplumsal yaşamın gerçekliklerine temas eden simgeler, olgular kişiler ve değerler üzerinden temellendirilen tüketim zincirinin önemli bir halkası olarak reklamlar gelmektedir. Bu noktada göze çarpan temel nokta; reklamların, oluşturdukları kadınlık ve annelik temsiliyle patriyarkal hiyerarşik yapılanışa alternatif metinler geliştirememesidir. Söz konusu her ürün ve hizmet, anneliği yücelten toplumsal değerlerin sembo- 
lik kodlarıyla kendi reklam kampanyalarını biçimlendirmekte ve eleştirel bir dönüşümden ziyade doğallaştıran bir yeniden üretim gerçekleştirmektedir.

Bu noktada eleştirel feminist teorinin dikkat çektiği toplumsal cinsiyet temelli yapısal problemlerin görünürlüğünü talep etmek ve üretilen reklam kurgularının tüketim kültüründen ayrıştırılarak eleştirel bir perspektifle annelik kurgusuna dair bir yeniden inşa süreci başlatabilmesini beklemek de bir ütopya olarak değerlendirilebilir. Fakat bu kabulün kanıksanması da beraberinde eleştirel feminist paradigmanın önemsediği farkındalığın yaratılmasını güçleştirecektir. Bu anlamda hâkim ideolojik kalıplardan ve sermaye örüntülerinden sıyrılarak alternatif sesleri duyurabilen medya araç ve ürünlerinin katkı potansiyeli taşıdığı görülmektedir. Ayrıca medya çalışanları içerisinde eleştirel bir farkındalıkla araçları yönlendirebilen ve ürünleri sorgulayarak geliştiren niteliksel ve niceliksel anlamda yeterli kadın istihdamının sağlanabilmesi de oldukça önemlidir. Fakat bütünsel anlamda toplumsal cinsiyet pratikleri ve ataerkil sistem, sermaye ilişkileri ve kurumsal örüntülerin işleme mekanizmalarına yönelen eleştirel değerlendirmelerin katkısı çok daha hayatidir. Tüm bu sorgulama pratikleri gündelik yaşamda doğal ve meşru kabul edilen kurgusallıklara yaklaşırken ceplerdeki soru işaretlerini hatırlamayı gerektirecektir. Bu sayede Virginia Woolf' un belirttiği özerkleşerek özgürleşen "Kendine Ait Bir Oda"nın kapıları, kadınlar için ve onların belirledikleri koşullarda ardına kadar aralanacaktır. 


\section{Kaynakça}

ALANKUŞ, S. (2009) Yeni habercilik arayışları: hak odaklı habercilik, yurttaş gazeteciliği, barış gazeteciliği. ALANKUŞ, S. (der.) içinde. Gazeteciliğe başlarken okuldan haber odasına. İstanbul: IPS İletişim Vakfı Yayınları, s. 88-124.

BAUDRILLARD, J. (1997) Tüketim toplumu. Çev: Hazal. Deliçaylı \& Ferda Keskin. İstanbul: Ayrıntı Yayınları.

BERGER, A. A. (1991) Media analysis techniques: revised edition. The Sage CommText series, vol. 10, Sage.

BHASIN, K. (2003) Toplumsal cinsiyet. Çev: Ayşe Coşkun. İstanbul: Kadınlarla Dayanışma Vakfı Yayınları.

ÇELENK, S. (2010) Kadınların medyada temsili ve etik sorunlar. ÇAPLI, B., veTUNCEL, H. (der.) içinde. Televizyon haberciliğinde etik. Ankara: Fersa Matbaacilik, s. 229-236.

DAĞTAŞ, B. (2003) Reklamı okumak. Ankara: Ütopya Yayınevi.

DEMİRBİLEK, S. (2007) Cinsiyet ayrımcılığının sosyolojik açıdan incelenmesi. Finans Politik \& Ekonomik Yorumlar Dergisi, 44 (511), s. 12-27.

DOĞANAY, Ü. ve KARA, İ. (2011) Tecavüzün münferit bir olay olarak çerçevelenmesi: yazılı basında Pippa Bacca haberleri. İletişim Araştırmaları Dergisi, 9 (1-2), s. 73-97.

DÖKMEN, Z. (2004) Toplumsal cinsiyet: sosyal psikolojik açılamalar. İstanbul: Sistem Yayıncilik.

ECEVİT, Y. (1993) Aile kadın ve devlet ilişkilerinin değerlendirilmesinde klasik ve yeni yaklaşımlar. Kadın Araştırmaları Dergisi, Sayı:1, s. 9-34.

ELDEN, M., ULUKÖK, Ö. ve YEYGEL, S. (2011) Şimdi reklamlar. İstanbul: İletişim Yayınları.

FOUCAULT, M. (2005) Entelektüelin siyasi işlevi. Çev: Ferda Keskin, Osman Akınhay ve Işık Ergüden. İstanbul: Ayrıntı Yayınevi.

GENCEL-BEK M. ve BİNARK M. (2000) Medya ve cinsiyetçilik. Ankara Üniversitesi Kadın Sorunları Araştırma ve Uygulama Merkezi ve KADER Eğitim Kitapçı̆̆ı. http: / / eski.bianet.org/2006/02/22/medya_ve_cinsiyetcilik_ kasaum.doc [Erişim Tarihi: 21 Ekim 2014]

HALL, S. (1980). Encoding/ decoding. HALL, S. vd. (der.) içinde. Culture, Media and Language: Working Papers in Cultural Studies 1972-79. London: Hutchinson, s. 128-138. 
TİMİİ, N. (1997) Medyada cinsiyetçilik. Başbakanlık Kadının Statüsü ve Sorunları Genel Müdürlüğ̈̈, Ankara: TTK Basımevi.

TOLUNGÜÇ, A. (1999) Turizmde tanıtma ve reklam. Ankara: Mediacat Yayınları.

WILLIAMSON, J. (2001) Reklamlarn dili: reklamlarda anlam ve ideoloji. Çev: Ahmet Fethi. Ankara: Ütopya Yayınevi.

WOOLF, V. (2012) Kendine ait bir oda. Çev: İlknur Özdemir. İstanbul: Kırmızı Kedi.

VAN DIJK, T. A. (1985) News Analysis: case studies of international and national news in the press. New Jersey: Lawrence Erlbaum Associates Publication.

VEFİKULUÇAY, D. vd. (2007) Kafkas Üniversitesi son sınıf öğrencilerinin toplumsal cinsiyet rollerine ilişkin bakış açıları. Hemşirelik Yüksek Okulu Dergisi, 14(2), s.26-38. http:/ / hacettepehemsirelikdergisi.org/pdf/pdf_HHD_36.pdf [Erişim Tarihi: 13 Eylül 2014]. 
$86<$ ilef dergisi • ilef journal 